\title{
El birrete de santa Teresa y la ciencia infusa. Creación y expansión de un nuevo modelo femenino en el arte novohispano
}

\section{Saint Teresa's Biretta and Infused Science. Creation and Expansion of a New Female Model in New Spain Art}

Artículo recibido el 9 de enero de 20I7; devuelto para revisión el I2 de marzo de 20I7; aceptado el 25 de abril de 20I7, http://dx.doi.org/IO.2220I/iie.I8703062e.20I8.II2.2626

Antonio Rubial García Universidad Nacional Autónoma de México-Facultad de Filosofía y Letras, México. abrugarcia49@gmail.com

Líneas de investigación Historia social y cultural de la Nueva España.

Lines of research Social and Cultural History of New Spain.

Publicaciones más relevantes El convento agustino y la sociedad colonial (I533-1630) (Ciudad de México: Universidad Nacional Autónoma de México-Instituto de Investigaciones Históricas, 1989); Una monarquía criolla (La provincia agustina de México en el siglo XVII) (Ciudad de México: Consejo Nacional para la Cultura y las Artes, 1990); La hermana pobreza. El franciscanismo: de la Edad Media a la evangelización novohispana (Ciudad de México: Universidad Nacional Autónoma de México-Facultad de Filosofía y Letras, 1996); La santidad controvertida: hagiografía y conciencia criolla alrededor de los venerables no canonizados de Nueva España (Ciudad de México: Universidad Nacional Autónoma de México/Fondo de Cultura Económica, 1999); La evangelización de Mesoamérica (Ciudad de México: Consejo Nacional para la Cultura y las Artes, 2002); Monjas, cortesanos y plebeyos. La vida cotidiana en la época de sor Juana (Ciudad de México: Taurus, 2005); Profetisas y solitarios (Ciudad de México: Universidad Nacional Autónoma de México/Fondo de Cultura Económica, 2006); El paraiso de los elegidos (Ciudad de México: Universidad Nacional Autónoma de México/ Fondo de Cultura Económica, 20Io); La justicia de Dios. La violencia fisica y simbólica de los santos en la historia del cristianismo (Madrid y Ciudad de México: Trama Editorial-Educación y Cultura. Asesoría y Promoción, 20II); coordinador y coautor del libro La Iglesia en el México colonial (Ciudad de México: Universidad Nacional Autónoma de México-Instituto de Investigaciones Históricas, 2013). 
Resumen En el siglo XviII novohispano se extendieron de manera notable las representaciones en las cuales santa Teresa portaba como uno de sus atributos el birrete doctoral de teología; dicho objeto era un atributo propio de los varones universitarios que estaban vinculados con dicha facultad. El tema estaba muy relacionado con una propuesta escolástica: las mujeres podían conocer los misterios divinos, sin mediar el estudio de los textos sagrados, gracias a la ciencia infusa. La vida y obra de santa Teresa de Ávila se insertó en ese supuesto y, al ser considerada sabia, comenzó a representarse no sólo en su papel de escritora, sino también en el de doctora de la Iglesia. En la Nueva España se volvió muy común en el siglo xviII colocar un birrete doctoral de teología en las imágenes pintadas y esculpidas de la santa de Ávila para simbolizar su sabiduría, la cual se mencionó también en diversos sermones. Dicho atributo, al igual que la pluma, el tintero y el escritorio, comenzaron a difundirse tanto en otras representaciones de mujeres santas, como en algunas de escritoras contemporáneas. El enorme influjo mediático de santa Teresa pudo influir en una nueva perspectiva sobre la capacidad femenina para el conocimiento.

Palabras clave Teresa de Ávila; escritura femenina; género y pintura; ciencia infusa.

Abstract In I8th century New Spain, representations of Saint Teresa wearing a biretta as one of her attributes increased significantly; this was an object worn by men who had taken a doctorate in a pontifical faculty and gives Saint Teresa the symbolic status of a "doctor in theology." The subject was closely related to a thesis of scholastic tradition: women could know the divine mysteries without the study of sacred texts, as a result of infused science, knowledge divinely conferred. The life and work of St. Teresa of Avila gave credence to this assumption and, in view of her patent wisdom (which was also mentioned in several sermons), she was represented not only as a writer, but also as a Doctor of the Church. In I8th century New Spain it became customary to include a symbolic doctoral biretta in painted and sculpted images of the saint from Avila. This attribute-as well as the pen, inkwell and desk-, came to be extended to representations of other saintly women as well as those of certain contemporary female authors. St. Teresa's enormous media impact may have influenced a new perspective on women's capacity for knowledge.

Keywords Teresa de Ávila; women's writing; gender and painting; infused science. 


\author{
ANTONIO RUBIAL GARCÍA \\ UNIVERSIDAD NACIONAL AUTÓNOMA DE MÉXICO \\ FACULTAD DE FILOSOFÍA Y LETRAS \\ MÉXICO
}

\title{
El birrete de santa Teresa y la ciencia infusa \\ Creación y expansión de un nuevo modelo femenino en el arte novohispano
}

\begin{abstract}
n 1606 salía en Zaragoza la primera edición de la Vida, virtudes y mila4 gros de la bienaventurada virgen Teresa de Jesús, firmada por Jerónimo fray Diego de Yepes (I530-1613), quien por entonces era obispo de Tarazona. La obra estaba inmersa en el proceso de beatificación abierto en Roma de quien sería considerada una de las mayores santas de la cristiandad católica de la Contrarreforma. El autor expresaba con estas palabras el excepcional favor que Dios había concedido a tan excepcional mujer y que se conocía en su tiempo como ciencia infusa:
\end{abstract}

Esta sabiduría infundió Dios a la Santa Madre con grande abundancia; porque como ella antes fuese muy ruda y inhábil, no sólo para decir las cosas espirituales, sino también para entenderlas, en brevísimo tiempo la dio el Señor tanta luz y tanta inteligencia de las cosas sobrenaturales y divinas, cual grandes teólogos con muchos años de estudio no pudieran alcanzar. Espantábase la Santa Madre de esta mudanza y admirábanse también los confesores como los que entonces no descubrían los fines que Dios en esto tenía: porque la había escogido por Maestra y Doctora de espíritu. ${ }^{\mathrm{I}}$

I. Diego de Yepes, Vida, virtudes y milagros de la bienaventurada virgen Teresa de Jesís, 2 vols. 
IO2

ANTONIO RUBIAL GARCÍA

El autor jerónimo continuaba diciendo que la Santa Madre había obtenido tal don "por medio de la oración" y que los libros que escribió estaban "llenos de admirable doctrina". El mismo autor explicaba que ese "altísimo conocimiento de las cosas divinas", no sólo se adquiría por medio de revelaciones que "pasan presto y no está en manos de quien las recibe usar de ellas cuando quiere”. La ciencia infusa en cambio era: "una sabiduría divina, no alcanzada con industria ni estudio humano, sino que es una Teología que viene de arriba, y se aprende cursando en la escuela del cielo, donde lee la cátedra la misma sabiduría, que es Dios". Se le llama también "teología mística y secreta" y no es adquirida por especulación, "sino infundida por el Espíritu Santo en el corazón de aquellos a quien él escoge para maestros y doctores de espíritu". Gracias a esa ciencia "le nacía entender muchas cosas de la Sagrada Escritura maravillosamente; de tal manera que algunos hombres doctos, después que trataban con ella, confesaban que entendían muchos lugares de ella, cuyo sentido antes no habían penetrado". ${ }^{2}$

\section{La ciencia infusa, una puerta de entrada}

El tema de la ciencia infusa venía definiéndose desde la escolástica y ya santo Tomás lo mencionaba en la Suma Teológica respecto al conocimiento absoluto que tuvo el alma humana de Cristo. ${ }^{3}$ Después de él, varios autores como Raimundo Lulio ( $c a$. I232-I315) en el Blanquerna y sobre todo los escritores místicos del Renacimiento y del barroco mencionaban que esta facultad la habían tenido Adán y la Virgen María, quienes habían recibido de Dios todo el conocimiento sin mediar los sentidos ni el razonamiento. ${ }^{4}$ Desde la Edad Media, estos favores se atribuían a los místicos, hombres y mujeres, pero la posibilidad de plasmarlos por escrito para su difusión había sido un privilegio casi

(Madrid: Plácido Barco López, I797), vol. II, lib. III, cap. XVIII, I56 y ss. Aunque se ha probado que la obra la escribió fray Tomás de Jesús, he preferido utilizar la atribución original del texto.

2. De Yepes, Virtudes y milagros.

3. Tomás de Aquino, Suma Teológica, I6 vols. (Madrid: BAC, 20Io), trat. III, q. II y I2.

4. Se puede consultar la edición reciente del Blanquerna de Raimundo Lulio (Madrid: BAC, 2009). Entre los autores que trataron el tema en el Renacimiento y el barroco se encuentran Dionisio el Cartujano, Jan van Ruysbroeck, Hendrik Harphius, Juan de Santo Tomás, Tomás de Jesús y José del Espíritu Santo. Ermanno Ancilli, Diccionario de espiritualidad, 3 vols. (Barcelona: Herder, 1987), vol. I, 386 y ss. 
exclusivo de los varones. Desde el siglo xII y con el surgimiento de una profusa actividad visionaria por parte de las mujeres, los confesores comenzaron a solicitar a sus dirigidas que escribieran sus visiones, pero estos manuscritos estaban destinados a ser leídos sólo por ellos. ${ }^{5}$ Dicha actividad no se consideraba como un acto social, sino como algo personal e íntimo. Es por esto que en la plástica, más bien tardía, que representa a mujeres santas, el papel más destacado no lo tuvieron las escritoras sino las mártires, convertidas gracias a su muerte violenta en "otros Cristos"; y en segundo lugar las místicas, a quienes se les representaba con sus visiones pero muy rara vez en su actividad literaria y sus imágenes estaban apenas circunscritas a algunos manuscritos. Una de esas figuras fue Hildegarda de Bingen (I098-II79), destacada en actividades intelectuales y místicas, pero que al no estar canonizada ni ser su escritura reconocida por la Iglesia como inspirada (esto pasó hasta el siglo xx), sus representaciones fueron escasas.

En otra situación debemos situar a las dos santas del siglo XIV que inauguraron el tema de la escritura pública femenina. En la terciaria dominica Catalina de Siena, canonizada en I46i por Pío II, sus biógrafos (como Raimundo de Capua) pusieron especial énfasis en los "favores" que Cristo le hacía durante sus éxtasis, los cuales la santa "describía” y eran "capturados" por sus secretarios y seguidores. ${ }^{6}$ Es por ello que en las pinturas sobre su vida se privilegiaban ese tipo de escenas (como la que la mostraba acercándose a la llaga del leproso y después a la de Cristo), y aunque a veces se le representaba con un libro en las manos (el Diálogo de la divina providencia), nunca la iconografía de esa época la mostró en una posición teológica de escritora. Distinto fue el caso de santa Brígida de Suecia (1303-I373), viuda, abadesa y fundadora de una orden religiosa, quien tuvo un importante papel en el regreso del papado a Roma después del "cautiverio" de Aviñón. Durante el Gran Cisma se impulsó su fama como escritora mística, lo que motivó su temprana canonización en I39I. Dentro de ese mismo contexto sus Revelaciones se tradujeron al latín por sus discípulos y, gracias a los oficios de Alfonso de Jaén, fueron utilizadas para sostener la legi-

5. Sobre la mística femenina medieval se pueden consultar: Caroline Walker Bynum, Fragmentation and Redemption. Essays on Gender and the Human Body in Medieval Religion (Nueva York: Zone Books, 1992). Y de la misma autora: Holy Feast and Holy Fast. The Religious Significance of Food to Medieval Women (Los Ángeles y Berkeley: University of California Press, 1987).

6. Las obras de Catalina de Siena están publicadas en la BAC (Madrid: 1980). La biografía de Raimundo de Capua sobre la santa tiene una edición en castellano (Barcelona: La Hormiga de Oro, 1993). 
timidad de los obispos romanos Urbano VI y Bonifacio IX (quien la canonizó) frente a las pretensiones del de Aviñón, Clemente VII. Una vez terminado el conflicto en I4I5 y reconocida la canonización anterior por Martín V, la figura de santa Brígida como escritora tuvo una gran difusión y sus Revelaciones, cargadas de tintes apocalípticos, sirvieron de inspiración a varios autores. ${ }^{7}$ Sin embargo, su iconografía insistió sobre todo en su papel de abadesa fundadora y de visionaria mística y en muy pocas ocasiones fue representada escribiendo, sobre todo en libros miniados dirigidos a unos cuantos monjes lectores. ${ }^{8}$

Brígida y Catalina son los primeros ejemplos de cómo se utilizó la escritura femenina con fines políticos y de qué manera la capacidad mística de las mujeres, como receptoras de mensajes divinos, podía avalar a una facción o una postura. Además quedaban fusionadas escritura, santidad y reconocimiento como parte de esta nueva percepción sobre las mujeres. Pero ¡este papel de mediadoras las convertía en teólogas autorizadas? Es dudoso, pues en ambos casos sus escritos se sometieron a dictámenes expertos y no siempre dichas escritoras salieron bien libradas. Las críticas que Brígida hacía a las autoridades eclesiásticas le valieron la descalificación de varios teólogos en el siglo xv, y es bien conocida la opinión adversa que tenía sobre Catalina de Siena el afamado teólogo de París, Jean Gerson. ${ }^{9}$

Por ello, las representaciones plásticas más comunes alrededor del tema de la escritura teológica fueron las de los personajes masculinos, sobre todo los doctores de la Iglesia san Jerónimo y san Agustín, quienes, coronados con su halo de santidad, sostenían una pluma y ostentaban sobre sus cabezas el capelo cardenalicio o la mitra episcopal. Su prestigio como pilares de la Iglesia y sus muchos años de estudio les otorgaban el aval de que escribían "autorizadamente" sobre la teología, considerada la "ciencia" suprema. La ortodoxia de las mujeres escritoras, en cambio, era dudosa y nacía del prejuicio de considerar que su intelecto no les permitía acceder a las complejas disquisiciones teológicas y al entrar en ese terreno podían ser engañadas por el demonio. Poseían, sí, una gran capacidad

7. El libro de las Revelaciones celestiales de Santa Brígida de Suecia puede consultarse en: http:// aparicionesdejesusymaria.wordpress.com. Sobre su vida y su obra véase Néstor Daniel Villa, Santa Brigida de Suecia: su orden, sus escritos (Madrid: Ediciones Tres Américas, 1997).

8. Claudio Leonardi, Andrea Riccardi y Gabriella Zarri, Diccionario de los santos, 2 vols. (Madrid: Ediciones San Pablo, 2000), I, 393 y ss., 458 y ss.; Louis Réau, Iconografía del arte cristiano, 5 vols. (Barcelona: Ediciones del Serbal, I997), III, 244 y ss. 284 y ss.

9. Sobre este tema consúltese Valerio Lazzeri, Teologia mistica e teologia scolastica: l'esperienza spirituale come problema teologico in Giovanni Gerson (Milán: Glossa, 1994). 
emotiva, sus corazones se inflamaban con la inspiración del Espíritu, pero podían caer muy fácilmente en el error, como lo demostraban las herejías alumbradistas del siglo Xv, en las cuales las beatas tuvieron una participación muy activa. ${ }^{\circ}{ }^{\circ}$

Esa supuesta incapacidad femenina para los estudios formales llevó a que la "ciencia infusa" se volviera el territorio en el cual las mujeres tuvieron cada vez más presencia, pues en él lectura y escritura ocupaban un papel secundario. Poco a poco ambos saberes, el adquirido por los estudios y el infuso, se equipararon, sobre todo como reacción a las críticas contra la experiencia mística que hicieron los movimientos humanistas de renovación cristiana y el protestantismo. ${ }^{\text {II }}$ No obstante, incluso en los que la aceptaban, la presencia de una "ciencia infusa" en las mujeres siempre debía estar sujeta a los dictámenes de un director de conciencia que avalara su veracidad y su ortodoxia; ya que ambos saberes no podían ser opuestos, era necesaria la supervisión masculina para que la debilidad e impericia de las mujeres no las hiciera víctimas del engaño demoniaco.

En vida, Teresa de Ávila tuvo que enfrentar esos prejuicios por parte de sus confesores, pero no es mi interés en este artículo abordar el tema de la obra mística de la santa, ya profusamente estudiado, ni de su gran influencia en la literatura femenina posterior, sino trabajar el alcance iconográfico que tuvo su figura como escritora después de muerta, la gran publicidad que comenzó a recibir gracias a la imprenta y, de manera tangencial, su incidencia en el cambio de mentalidad alrededor de la capacidad femenina para acceder al conocimiento teológico.

\section{Santa Teresa y su birrete en España}

María José Pinilla Martín, en su sobresaliente tesis de doctorado de la Universidad de Valladolid sobre la iconografía de la santa de Ávila, señala la temprana presencia del tema de la escritura como parte central de la propaganda teresiana con miras a su proceso de beatificación (iniciado en 159I), tanto en grabados, como en pinturas y esculturas. Su representación con una pluma en la mano y un libro fue tan importante como la famosa de la transverberación. ${ }^{\mathrm{I2}}$ Ya desde

Io. Marcel Bataillon, Erasmo y España, estudios sobre la historia espiritual del siglo XVI, trad. Antonio Alatorre (México: Fondo de Cultura Económica, 1966), 6r y ss.

II. Sobre este tema se puede consultar Leszek Kolakowski, Cristianos sin Iglesia. La conciencia religiosa y el vínculo confesional en el siglo XVII (Madrid: Taurus, 1982), 239 y ss.

I2. María José Pinilla Martín, "Iconografía de santa Teresa de Jesús", tesis de doctorado (Universidad de Valladolid-Facultad de Filosofía y Letras-Departamento de Historia del Arte, s. f.), 639 y ss. 
I599, esta autora señala, en la versión italiana de su Vida, escrita por el jesuita Francisco de Ribera (publicada en I590), que aparece el tipo iconográfico de la santa frente a su escritorio con libro abierto, tintero y pluma y la paloma que la inspira. Rubens, Ribera, Zurbarán, Herrera y todos los pintores que trataron ese tema seguirán el mismo modelo. La escultura en cambio la representará de pie, no sentada, pero con los mismos atributos. ${ }^{13}$

Con la consumación de su meteórico proceso de beatificación (I6I4) seguido de su rápida canonización (I622), la imagen mediática de la santa se volvió incuestionable, no sólo para la Península Ibérica y sus colonias sino para todo el ámbito católico. Junto con Ignacio de Loyola, Teresa de Ávila se constituiría en un símbolo de hispanidad y catolicidad, en el emblema de la lucha del imperio contra las potencias protestantes secuaces del demonio. Un nuevo hito en la difusión de dicha propuesta fueron dos intentos fallidos por nombrarla patrona de las Españas, uno (después de su beatificación) por parte de las Cortes de Castilla con la aprobación de Felipe III, y el otro más tardío (con su canonización) apoyado por el Conde Duque de Olivares bajo el reinado y apoyo de Felipe IV; la propuesta desató una conflictiva disputa con la catedral compostelana, que insistía en la exclusividad del patronato para Santiago apóstol, un guerrero invicto que se "negaba" a aceptar un copatronazgo sobre España (en esa década en la que la guerra de treinta años enfrentaba a católicos y protestantes) y menos con una mujer "pacificadora". ${ }^{\mathrm{I}}$

Muy posiblemente en esa segunda polémica, que se dio entre I626 y I630, y ante el fracaso de la propuesta de un patronato compartido, comenzó la representación de santa Teresa con un birrete como atributo. Debió ser a partir de entonces que las esculturas de la santa comenzaron a mostrarse ataviadas con el birrete doctoral durante las procesiones, quizá por la injerencia que los doctores de la Universidad de Salamanca tuvieron en el proceso de beatificación y canonización. Es muy probable que en ese ambiente haya aparecido la primera obra con ese atributo realizada por Alonso Cano en 1629, y que formó parte del retablo que encargó Francisco de Ortega y su esposa en 1628, con destino

13. Otras dos vidas se publicaron a principios del siglo xvir: la de fray Juan de Jesús María en I609, en latín; y la que firmó fray Diego de Yepes (Zaragoza, I606). María José Pinilla señala que se ha probado que esta última obra en realidad la escribió fray Tomás de Jesús. Pinilla Martín, "Iconografía de santa Teresa", 23.

I4. Pinilla Martín, "Iconografía", 299 y ss. Véase también Erin Rowe, Saint and Nation: Santiago, Teresa of Avila, and Plural Identities in Early Modern Spain (Pennsylvania State University Press, 20II). 
a la iglesia del Colegio de San Alberto de Sicilia, perteneciente al Carmen Calzado. ${ }^{15}$ Esas esculturas debieron servir de modelo para algunos grabados, siendo el primero en el cual la santa presentaba ese atributo que ilustra la portada del libro Avisos espirituales de santa Teresa de Jesús comentados por el padre Alonso de Andrade de la Compañía de Jesús. ${ }^{6}$ En ella, dicho objeto está colocado sobre el altero de libros que son sus obras. Poco a poco dicho artículo comenzó a tener una fuerte presencia en los grabados hasta volverse un atributo propio de la santa de Ávila en el siglo xviıI; en algunos ejemplos que resguarda la Universidad de Navarra, el birrete sobre la cabeza de la santa y portar un libro y una pluma en las manos demuestran su destacado papel doctoral. ${ }^{17}$

Ningún autor moderno ha insistido en este atributo, que se volvió sumamente popular a partir de finales del siglo Xvir. María José Pinilla Martín lo trata de manera muy tangencial en su tesis y lo considera sólo una variante de la iconografía de la "santa escritora". El tema, según ella, se volvió más popular en el siglo XviII en inscripciones y grabados que se referían a santa Teresa como Doctrix Seraphica, a veces en paralelo con el Doctor Angelicus, santo Tomás de Aquino. ${ }^{18} \mathrm{La}$ autora agrega una variante muy importante del tema, en la cual se le representa como maestra de doctores, de la que existen dos ejemplos: uno en el convento carmelita de Toro, en Zamora, que muestra a la catedrática coronada con una guirnalda de flores; otro, un lienzo del xvin en la iglesia parroquial de Pastrana donde la santa aparece perorando desde una cátedra, con su birrete a un lado y ante un grupo de doctos varones que la escuchan extasiados. El lienzo, que debió estar en el convento carmelita de San Pedro de dicha ciu-

I5. María Dolores Mármol Marín, "Cuatro imágenes de la iconografía carmelitana en la escultura barroca andaluza”, Cuadernos de Arte e Iconografía. Revista virtual de la Fundación Universitaria Española, VI, I2 (1993): 22-28 (www.fuesp.com). La autora señala que en la imagen se presenta a la santa con los atributos que la distinguen como doctora de la Iglesia: en una mano la pluma delicadamente sujeta, en la otra el libro y la cabeza cubierta con el birrete característico de su grado. Según la misma autora, al desaparecer el convento en el siglo XIX se perdió parte del retablo, pero se salvó esta magnífica escultura que pertenecía a la época sevillana del maestro Cano y que se encuentra en la actualidad en la iglesia de Nuestra Señora del Buen Suceso de Sevilla. Algunos autores piensan que el birrete es posterior, pero esto no invalida la posibilidad de que la escultura haya sido utilizada para procesiones y que el birrete se le haya colocado con tal finalidad.

16. Avisos espirituales de santa Teresa de Jesús comentados por el padre Alonso de Andrade de la Compañia de Jesús (Madrid: Gregorio Rodríguez, 1647).

17. Estos ejemplos se pueden ver en: www.unav.es/biblioteca/fondoantiguo/hufaexp32/orb.html.

I8. Pinilla Martín, "Iconografía", 644. Dicha autora pone el ejemplo de dos cuadros del convento de carmelitas descalzos en Ratisbona, Alemania, obras de Gottfried Eichler. 
IO8

ANTONIO RUBIAL GARCÍA

dad, tomó el modelo de un grabado de I73I que se encuentra en la Biblioteca Nacional de Madrid. ${ }^{19}$

Considero, sin embargo, que el tema del birrete tiene mayores implicaciones que las que Pinilla Martín descubre para la Península Ibérica y que no explora suficientemente, a pesar de que, al hablar de la escultura, esta autora muestre numerosos ejemplos de santa Teresa escritora de pie, teniendo en la mayoría de ellos el atributo del birrete.

\section{El tema se difunde en la Nueva España}

En el siglo XviII novohispano era una práctica común colocar un birrete a las esculturas procesionales de la santa, como se hace patente en dos cuadros que describen traslados de monjas. En el primero, en el templo de la Soledad de Puebla, las monjas carmelitas, trasladadas a su nueva casa por el obispo Pantaleón Álvarez Abreu, siguen a las imágenes de la Virgen y de la madre fundadora doctorada con su birrete (fig. I). En el segundo, en el Museo Regional Michoacano, las monjas dominicas de Valladolid llegan a su templo de Santa Catalina de Siena, donde las esperan las esculturas de los santos fundadores de las órdenes religiosas que tenían casa en la ciudad; la de los carmelitas está representada por una santa Teresa de Ávila que porta birrete (fig. 2). ${ }^{20}$

En 1756, el diarista José Manuel de Castro Santa Anna daba esta noticia del 9 de noviembre: en la última parte de las fiestas de celebración por la confirmación pontificia del patronato de la Virgen de Guadalupe sobre América, "la religión carmelitana en número de cien sujetos, [llevó] a la mística doctora santa Teresa, con hábito de tisú de plata guarnecido de diamantes y rubíes, y la borla del bonete toda de perlas netas gruesas, que valuaron su adorno en más de I00.000 pesos". ${ }^{21}$ Muy posiblemente de esta práctica procesional deriven las numerosas pinturas y grabados que se encuentran en España, en la Nueva España y en otros lugares de América, en las que Teresa de Ávila aparece rela-

19. Pinilla Martín, "Iconografía", 646.

20. El cuadro lo estudió Nelly Sigaut, "Azucenas entre espinas. El traslado de las monjas de santa Catalina de Siena en Valladolid, I738”, en Elena Estrada de Gerlero, ed., XVI Coloquio Internacional de Historia del Arte, El arte y la vida cotidiana (Ciudad de México: Universidad Nacional Autónoma de México-Instituto de investigaciones Estéticas, 1995), 199-215.

2I. José Manuel de Castro Santa Anna, Diario de sucesos notables, 3 vols. (Ciudad de México: Imprenta de Juan N. Navarro, I854), VI, 56. 




I. Pablo de Talavera, Traslado de las monjas carmelitas a su nueva casa por orden del obispo Pantaleón Álvarez Abreu (detalle), ca. 1748, óleo sobre tela. Templo de la Soledad de Puebla. Secretaría de Cultura-INAH-Méx. "Reproducción autorizada por el Instituto Nacional de Antropología e Historia”. 




2. Anónimo, Las monjas dominicas de Valladolid llegan a su nuevo templo de Santa Catalina de Siena (detalle), I738, óleo sobre tela. Museo Regional Michoacano. Secretaría de Cultura-INAHMéx. "Reproducción autorizada por el Instituto Nacional de Antropología e Historia".

cionada con el birrete doctoral, y que se volverá un referente obligado en una buena parte de las representaciones de la santa escribiente (fig. 3). Se debe tener en cuenta que los grabados serán una importante herramienta de expansión y publicidad del tema. El otro instrumento fueron los sermones, de los que se conservan dos impresos en Puebla y uno en la Ciudad de México, en los cuales se habla abiertamente de santa Teresa como doctora. ${ }^{22}$

El primero, publicado en $\mathrm{I719}$, con el título La quinta essencia de la virtud: santa Teresa de Jesús, sermón panegírico de sus glorias fue obra del carmelita fray Andrés de San Miguel, quien decía lo siguiente:

22. Los tres sermones los publicó y comentó Alejandra Soria Gutiérrez, Retórica sacra en la Nueva España. Introducción a la teoría y edición anotada de tres sermones sobre Santa Teresa, Colección Batihoja (Nueva York: Instituto de Estudios Auriseculares, 20I4), consultado el 17 de mayo de 2016, en www.ideauriseculares.com. 
3. José de Nava, Santa Teresa de Ávila como doctora, grabado, segunda mitad del siglo xvirI. Colección particular.

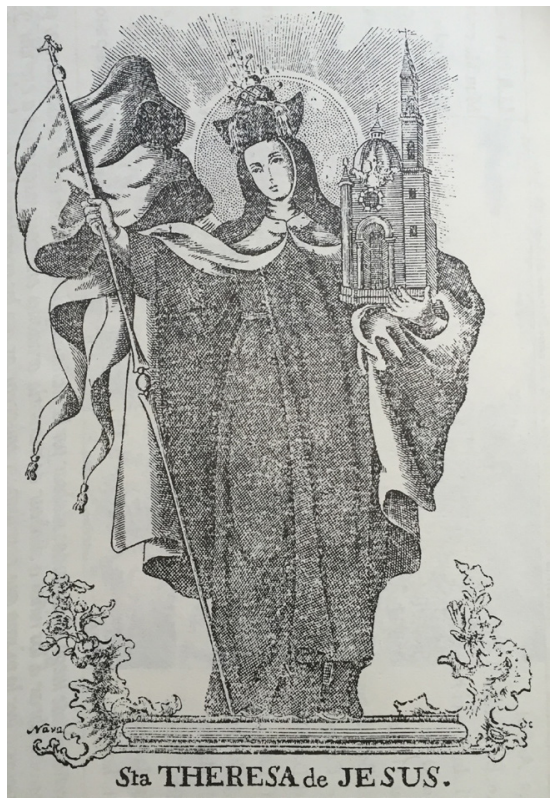

$\mathrm{Al}$ asombro milagroso de las mujeres, a la confusión de los hombres, a la admiración de los ángeles, a la que supo hacer lugar entre los mayores príncipes, monarcas y reyes, a la que tomó asiento entre los patriarcas más ilustres, a la que si toma la pluma reduce a claro y fácil estilo, todo lo que de la más recóndita y dificultosa teología dejaron sin orden esparcido en sus escritos los doctores sagrados, y que por esto se hizo lugar aún entre los doctores de la iglesia, dándole en la universidad del cielo la borla y título de celestial a su doctrina el sumo vicario de Cristo. ${ }^{23}$

Después de esta introducción, el autor comparaba a Teresa con una Palas "armígera y guerrera" y una "Minerva sabia", la llamaba "Doctora de la Verdad" y declaraba que su doctrina era "celestial". ${ }^{24}$

El segundo sermón, publicado en 1737 por el mercedario Juan de Salazar para las carmelitas de Puebla, lleva por título Vida del amor de Cristo estampada

23. El texto está en la biblioteca del Museo de Antropología. Andrés de San Miguel, La quinta essencia de la virtud: santa Teresa de Jesús, sermón panegírico de sus glorias (Ciudad de México: Herederos de Juan José Guillena Carrascoso, I719), f. I r.

24. San Miguel, La quinta essencia, f. I9 vta. 
en el corazón de Teresa. La tesis del autor era que Cristo se miró reflejado en Teresa como en un espejo y todos sus argumentos iban dirigidos a mostrar los paralelismos entre ambos personajes. En un arranque retórico, el autor llamaba a la santa

esclarecida matrona y felicísima heroína, en el merecer tan eminente que fue la honra de Espańa, lustre de la Europa, maestra de espíritus, doctora de las mansiones del cielo, profeta en tantos místicos presagios, como gritan sus libros, mártir en las adversidades, gloria de las vírgenes, Minerva de la sabiduría, vida de la observancia, alma de la aspereza y corazón de la gracia más portentosa. ${ }^{25}$

El tercer sermón, de título Sermón quinto y segundo de Santa Teresa de Jesús, lo escribió el jesuita Nicolás de Segura y se publicó en México en 1742, junto con otros en una colección. Por él sabemos que, en la bula de su canonización, el Sumo Pontífice declaró que la santa había alcanzado: "los puntos más arcanos de la teología mística con una sabiduría verdaderamente celestial", y los auditores de la Rota, "la calificaron doctora y maestra que Dios preparó para su Iglesia", por lo que concluía que debía ser considerada "en el gremio de los doctores". El jesuita agregaba: "nos veremos obligados a pronunciar, que en sola esta prodigiosa Virgen se halla una perfectísima copia y vivísimo retrato de toda la corte celestial y de todos y cada uno de los santísimos órdenes que la ennoblecen" ${ }^{26}$

Para el siglo xviII el doctorado de santa Teresa era ya vox populi, tanto así que en la Gaceta de México siempre que reseñaba la fiesta de la santa la llamaba con ese título. El Is de octubre de I73I, por ejemplo, se decía: “Todos los Conventos de Religiosos y Religiosas Carmelitas celebraron con gran solemnidad á la Seraphica Doctora Santa Teresa de Jesús y Ahumada, Madre y Maestra de tan Ilustre Reforma”. ${ }^{27}$

25. Juan de Salazar, Vida del amor de Cristo estampada en el corazón de Teresa. Sermón panegírico, que en la plausible fiesta que anualmente celebra el convento de carmelitas descalzas de esta ciudad de Puebla predicó... (Puebla: Viuda de Miguel de Ortega, 1737). Véase Soria Gutiérrez, Retórica sacra, 397.

26. De Salazar, Vida del amor de Cristo, 460 y 462.

27. Juan Francisco Sahagún de Arévalo y Juan Ignacio Castorena y Ursúa, Gaceta de México, 3 vols., núm. 47, introd. Francisco González de Cosío (Ciudad de México: Secretaría de Educación Pública, I949-I950), vol. I, octubre de I73I, 356. 
Estos sermones y noticias se hacían eco de la difusión de las representaciones pictóricas de santa Teresa portando el birrete doctoral, las cuales se volvieron sumamente populares en la Nueva España desde la última década del siglo XVII. La primera de ellas se inscribió en un cuadro firmado por Nicolás Rodríguez Juárez en 1695 que se encuentra en la iglesia del Carmen de Celaya. Un carruaje triunfal que aplasta herejes bajo sus ruedas y porta a la Virgen María llega escoltado por pontífices y obispos a las puertas monumentales de la casa carmelitana; frente a ella reciben al cortejo san Elías, el beato Juan de la Cruz y la madre fundadora santa Teresa de Ávila, los tres personajes portan en sus manos sendos birretes doctorales apoyados en libros (fig. 4).

Un segundo ejemplo, poco más tardío, se encuentra en un cuadro de ánimas firmado en 1708 por Cristóbal de Villalpando en el templo parroquial de Santiago Tuxpan, Michoacán, en cuyo centro está santa Teresa con un birrete a sus pies y cuyo patronato se debe a los condes de Miravalle. ${ }^{28}$ Es muy significativo que esta obra no se halle en contexto carmelitano, lo que prueba la gran difusión del culto y de la representación del doctorado teresiano en todos los ámbitos novohispanos (fig. 5). A partir de entonces el birrete se convertirá en atributo constante en la iconografía teresiana, siendo los ejemplos más notables los que se encuentran en la Ciudad de México y en Puebla. Lo más común es que el birrete aparezca asociado con su actividad de escritora, sobre su escritorio y en relación con la pluma que la mística sostiene en la mano; pero también constituye uno de sus principales atributos en las representaciones de santa Teresa acompañada por san Juan de la Cruz o por san Elías bajo el manto protector de la Virgen del Carmen. Por último, el birrete aparece en ocasiones coronando su cabeza, modelo directamente tomado de las esculturas procesionales.

¿Debemos considerar que estas representaciones novohispanas estaban influidas por la difusión de retratos de doctores universitarios que se daban en ese momento? En una muestra de casi 300 retratos que se conservan y que formaban parte de diversos acervos, entre ellos el de la universidad, se representó a los ilustres miembros de ella de pie y con el imprescindible birrete colocado a su lado. La mayor parte de los lienzos pertenecen a las últimas décadas del

28. Pedro Ángeles Jiménez elaboró la ficha catalográfica, véase Juana Gutiérrez Haces, Pedro Ángeles, Clara Bargellini y Rogelio Ruiz Gomar, Cristóbal de Villalpando (Ciudad de México: Fomento Cultural Banamex/Universidad Nacional Autónoma de México-Instituto de Investigaciones Estéticas, 1997), 322 y ss. 




4. Nicolás Rodríguez Juárez, Carro triunfal de la Virgen María llega al templo de la Jerusalén carmelitana, I695, Iglesia del Carmen de Celaya. Foto: Hugo Armando Félix Rocha.

siglo XVII y sobre todo al XVIII, etapa que coincide precisamente con la gran difusión del tema que ahora me ocupa. No resultaría extrańo que las representaciones de santa Teresa, con el emblema más característico de los egresados de dicha casa, pudieran estar influidas por ese auge que tuvo la retratística universitaria. ${ }^{29}$

Por otro lado, es muy sintomático que los carmelitas descalzos, orden que nunca tuvo cátedra universitaria en México, insistieran tanto en incluir el birrete doctoral de su santa fundadora, quizá como un acto simbólico para hacer patente su presencia teológica en un ámbito del que estaban excluidos. Esto también explicaría la insistencia en colocar birretes como parte de los emblemas de algunos santos varones de la orden o vinculados con ella. En el acervo

29. Sobre este tema véase el magnífico catálogo de la exposición coordinada por Clara Inés Ramírez, Armando Pavón y Mónica Hidalgo, Tan lejos, tan cerca. A 450 años de la Real Universidad de México (Ciudad de México: Universidad Nacional Autónoma de México, 20oI). 


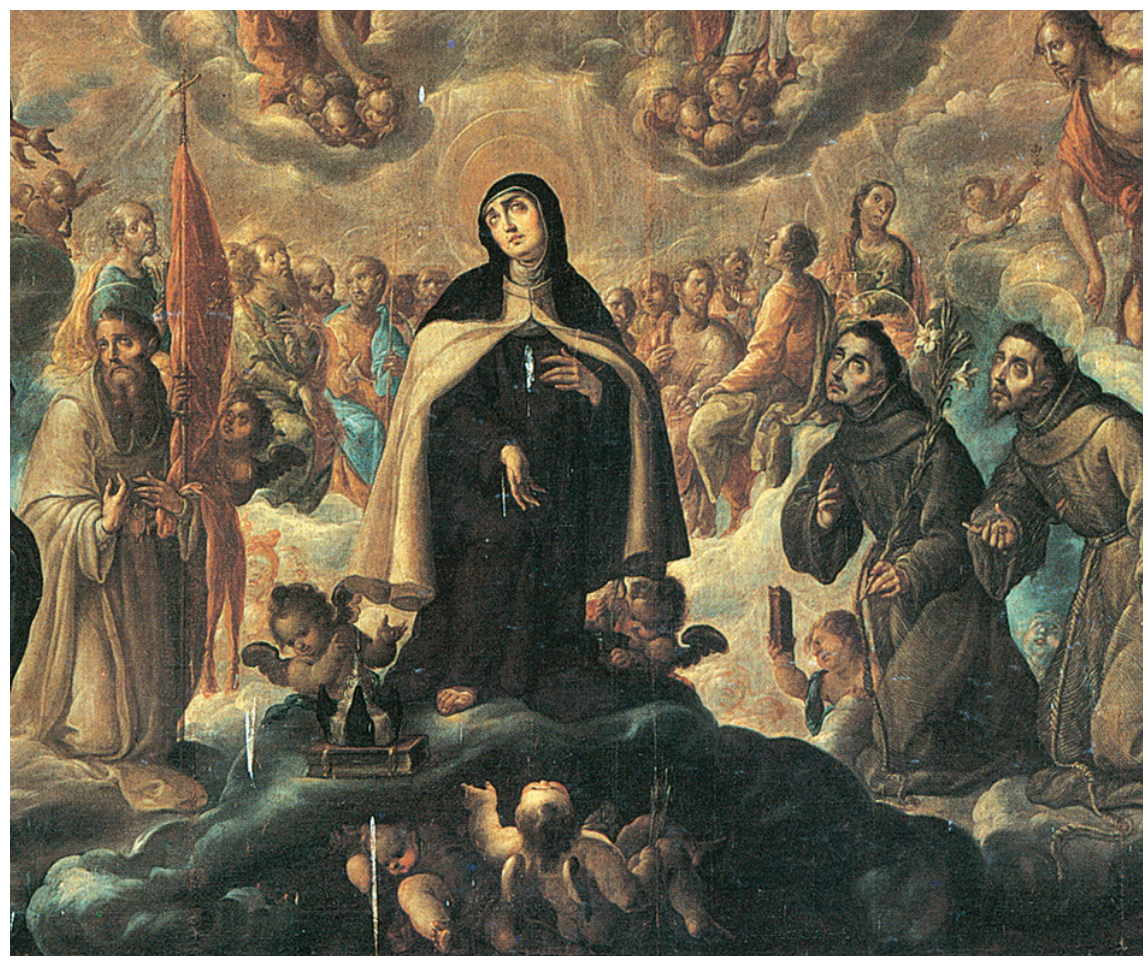

5. Cristóbal de Villalpando, Cuadro de ánimas con santa Teresa al centro, 1708, óleo sobre tela. Templo parroquial de Santiago Tuxpan, Michoacán. Secretaría de Cultura-InAH-Méx. "Reproducción autorizada por el Instituto Nacional de Antropología e Historia".

del Museo del Carmen en San Ángel, en los retratos de san Cirilo de Alejandría, san Cirilo de Constantinopla, san Isidoro Pelusiota, san Juan de la Cruz y san Cirilo de Jerusalén, todos representados como ilustres teólogos, el birrete aparece sobre su escritorio como parte de sus atributos..$^{30}$ Además de ellos, solamente los franciscanos tuvieron tal interés por mostrar a sus teólogos con ese emblema doctoral de manera tan ostensible, sobre todo a su doctor sutil Duns Scoto (defensor del inmaculismo), quien por no estar canonizado necesitaba mostrarse con ese emblema de autoridad. ${ }^{31}$

30. Catálogo de pintura del Museo del Carmen (Ciudad de México: Probursa, 1987), 88 y ss.

3I. Véase Antonio Rubial García, "Dos santos sin aureola. Las imágenes de Duns Scoto y la madre Águeda en la propaganda inmaculista franciscana”, en Peter Krieger, ed., XXVIII Coloquio 
Respecto a santa Teresa, ese afán por presentarla como doctora queda patente en dos grandes lienzos anónimos del siglo XviII que se encuentran en el templo del Carmen de San Ángel en la Ciudad de México y que pueden considerarse como paradigmáticos de tales representaciones. En uno aparecen varios frailes y monjas carmelitas presididos por los tres santos fundadores de la orden (entre ellos santa Teresa con el birrete a sus pies) y protegidos bajo el manto de la Virgen del Carmen, el cual está sostenido por la parentela celestial de María: san José, san Joaquín, santa Ana y san Juan Bautista, acompañados de grupos angélicos. El otro, más interesante para nuestro propósito, muestra a la santa de Ávila ante un escritorio en el acto de escribir y frente a ella, como en un espejo, santo Tomás en la misma actitud. Ambos santos reciben en su oído el soplo de la paloma del Espíritu Santo (simbolizando su ciencia infusa) y tienen a sus espaldas anaqueles de libros, complementos de su saber teológico. Este nuevo elemento, una biblioteca, es de suma importancia pues daba a la lectura un valor que no se oponía a la ciencia infusa, sino que le era necesaria. Frente a un Aquinate cuya fama teológica era incuestionable, al lado de santa Teresa unos angelillos juguetean con su birrete doctoral que muestra, en un guiño aparentemente anecdótico, la necesidad de equiparar su sabiduría a la del prestigiado teólogo dominico, pues ambas provenían de Dios (fig. 6). El centro de la imagen lo ocupa el venerado santo Cristo de Burgos, patrono de los mercaderes santanderinos, grupo con el que los carmelitas novohispanos tenían fuertes ligas y bajo cuyo mecenazgo se debió pintar el cuadro. ${ }^{32}$

La mayoría de estas representaciones se encontraban en templos y conventos de la orden, tanto masculinos como femeninos, sin embargo, existen algunos ejemplos en iglesias de otras órdenes y, sobre todo del clero secular. En el templo parroquial indígena de Yauhquemecan, en Puebla, en el intradós que remata el retablo mayor, se representó a la santa de pie, en actitud de escribir mientras un ángel atraviesa su corazón flotante con una flecha. Sobre su escritorio, junto al libro abierto y el tintero, un bonete doctoral colocado sobre otro

Internacional de Historia de Arte, La imagen sagrada y sacralizada, 2 vols. (Ciudad de México: Universidad Nacional Autónoma de México-Instituto de Investigaciones Estéticas, 20II), II, 563580. En el siglo xviII el birrete doctoral se volvió también atributo indispensable de otro santo muy popularizado por los jesuitas, san Juan Nepomuceno.

32. Sobre la relación entre los carmelitas y los santanderinos véase Víctor Manuel Cruz Lazcano, "Hermanos de sangre y religión. Oligarquías y la orden del Carmen en Nueva España borbónica", tesis de maestría en Estudios Virreinales (Ciudad de México: Universidad del Claustro de Sor Juana, 2016). 




6. Anónimo, Santo Cristo de Burgos con Santa Teresa y Santo Tomás escribientes, detalle, segunda mitad del siglo xvıII, óleo sobre tela. Templo del Carmen de San Ángel, Ciudad de México. Foto: Antonio Rubial.

libro cerrado avala que su saber teológico era incuestionable. ¿¿Quién pudo inspirar este cuadro sino el cura párroco de Yauhquemecan? Muy posiblemente bachiller egresado de la Universidad de México, este sacerdote tuvo interés por mostrar la sabiduría teológica de la santa, lo cual lo llevó a incluir en el lienzo encargado dicho birrete propio de los universitarios (fig. 7). Al igual que muchos otros detalles pictóricos, esta inclusión debió pasar inadvertida para sus feligreses indígenas, ajenos a tales sutilezas teológicas.

\section{El birrete doctoral se difunde para otras santas}

El cura de Yauhquemecan debió tener una especial devoción a santa Teresa y a santa Gertrudis, la otra santa que comparte con ella el espacio del intradós del retablo mayor. Sin embargo, los miembros de su corporación universitaria 


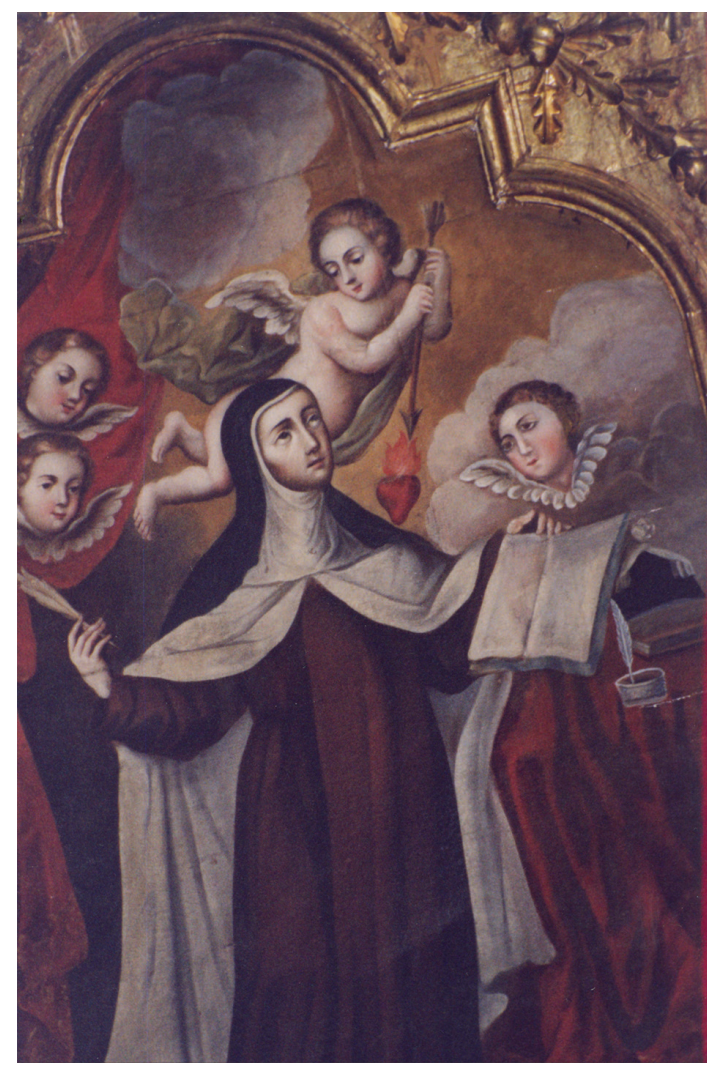

7. Anónimo, Santa Teresa de Jesús con el corazón traspasado, primera mitad del siglo xviII, óleo sobre tela. Templo parroquial de Yauhquemecan, Puebla. Foto: Doris Bieńko.

tenían su propia santa teóloga y mártir, Catalina de Alejandría, cuya fiesta como patrona de la institución se celebraba con gran aplauso el 25 de noviembre. A partir de que la universidad comenzó a ser controlada por el cabildo de la catedral y de que las órdenes perdieron presencia en ella, santa Catalina de Alejandría se convirtió en el símbolo "seglar" más importante de la corporación y a partir del siglo Xviı el birrete comenzó a ser uno se sus emblemas asociados, como lo muestra un cuadro de la santa con donante que se encuentra en una colección particular (fig. 8).

Santa Catalina de Alejandría, quien, según la Leyenda dorada de Jacobo de la Vorágine, había disputado con un grupo de filósofos antes de ser condenada al 
8. Anónimo, Santa Catalina de Alejandría con donante, finales del siglo xvir, óleo sobre tela. Colección particular.



martirio, se consideró como la patrona de la filosofía. ${ }^{33}$ En un cuadro de Baltasar de Echave Rioja fechado en I678 (en la actualidad en el Museo Nacional de Arte de la capital) se le representó disputando con los doctores. Esta obra fue realizada por encargo de Luis Martínez Hidalgo y Montemayor, egresado de Leyes de la Universidad de México y fiscal de las audiencias de Santo Domingo y Guadalajara, y formó parte del acervo universitario. Unos años atrás, el bachiller Pedro de la Vega, cura de la parroquia de Santa Catalina Mártir, imprimía en México, en 1672, un largo "poema heroico" sobre ella con el título La rosa

33. Jacobo de la Vorágine, Leyenda dorada, trad. José Manuel Macías, 2 vols. (Madrid: Alianza, I982), cap. CLXXII, II, 766. 
de Alejandria, entre flores de divinas y humanas letras, texto que debió inspirar a sor Juana Inés de la Cruz. ${ }^{34} \mathrm{El}$ cuadro estaba inmerso en una promoción que el clero secular, tan vinculado a la Universidad de México, realizaba alrededor del culto a esta santa.

En ese contexto, y bajo la influencia de las representaciones teresianas, es posible entender un enorme lienzo que representa la Dormición de la Virgen en la capilla de Mixtecos anexa al convento de Santo Domingo de Puebla. En él, dos figuras femeninas flanquean la figura de la Virgen ascendida a los cielos: santa Catalina de Siena y santa Catalina de Alejandría, ambas con el birrete doctoral coronando sus cabezas. Es muy significativa la referencia a la terciaria dominica, que hasta entonces había estado un poco opacada (fig. 9). Sus representaciones no son muy abundantes en las últimas décadas del XVII, pues la presencia de santa Rosa de Lima, también terciaria dominica e imitadora de su santidad y además criolla, recibió la atención de todo el aparato publicitario. Después de su meteórico proceso de beatificación y canonización (I668-I673) se convirtió en el paradigma de santidad femenina para los americanos, pero no como escritora sino como visionaria. ${ }^{35}$ A pesar de ello, la orden de Santo Domingo había sido desplazada por el clero secular como corporación rectora en la universidad, por lo que necesitaba darle difusión a la actividad intelectual de Catalina de Siena, que con su birrete se convertía en su timbre de orgullo como universitarios.

Además del cuadro de la capilla de Mixtecos de Puebla, en un segundo lienzo excepcional del siglo xviII, firmado por Pascual Pérez Salazar (m. I72I), que se encuentra en el Museo de Arte Religioso de Santa Mónica de Puebla, la santa de Siena es representada como doctora, con todos los atributos teresianos ya fijados por la tradición. En su cabeza porta el birrete doctoral, escribe de pie frente a su escritorio, contempla un crucifijo y tiene como fondo un mueble lleno de tratados místicos y comentarios sobre los evangelios. Como se ha visto la ciencia infusa ya no se consideraba como algo opuesto a la teología libresca, ambas se complementaban (fig. Io). En la segunda mitad del

34. Jaime Cuadriello, "Baltasar de Echave y Rioja. Santa Catalina de Alejandría discutiendo con los sabios", Catálogo comentado del acervo del Museo Nacional de Arte. Nueva España. Pintura, 2 vols. (Ciudad de México: Consejo Nacional para la Cultura y las Artes-Instituto Nacional de Bellas Artes/Universidad Nacional Autónoma de México/Patronato del Museo Nacional de Arte, 2004), II, 32I y ss.

35. Ramón Mujica, Rosa limensis: mistica, politica e iconografía en torno a la patrona de América (Lima: Fondo de Cultura Económica/Instituto Francés de Estudios Andinos, 200I), 65 y ss. 


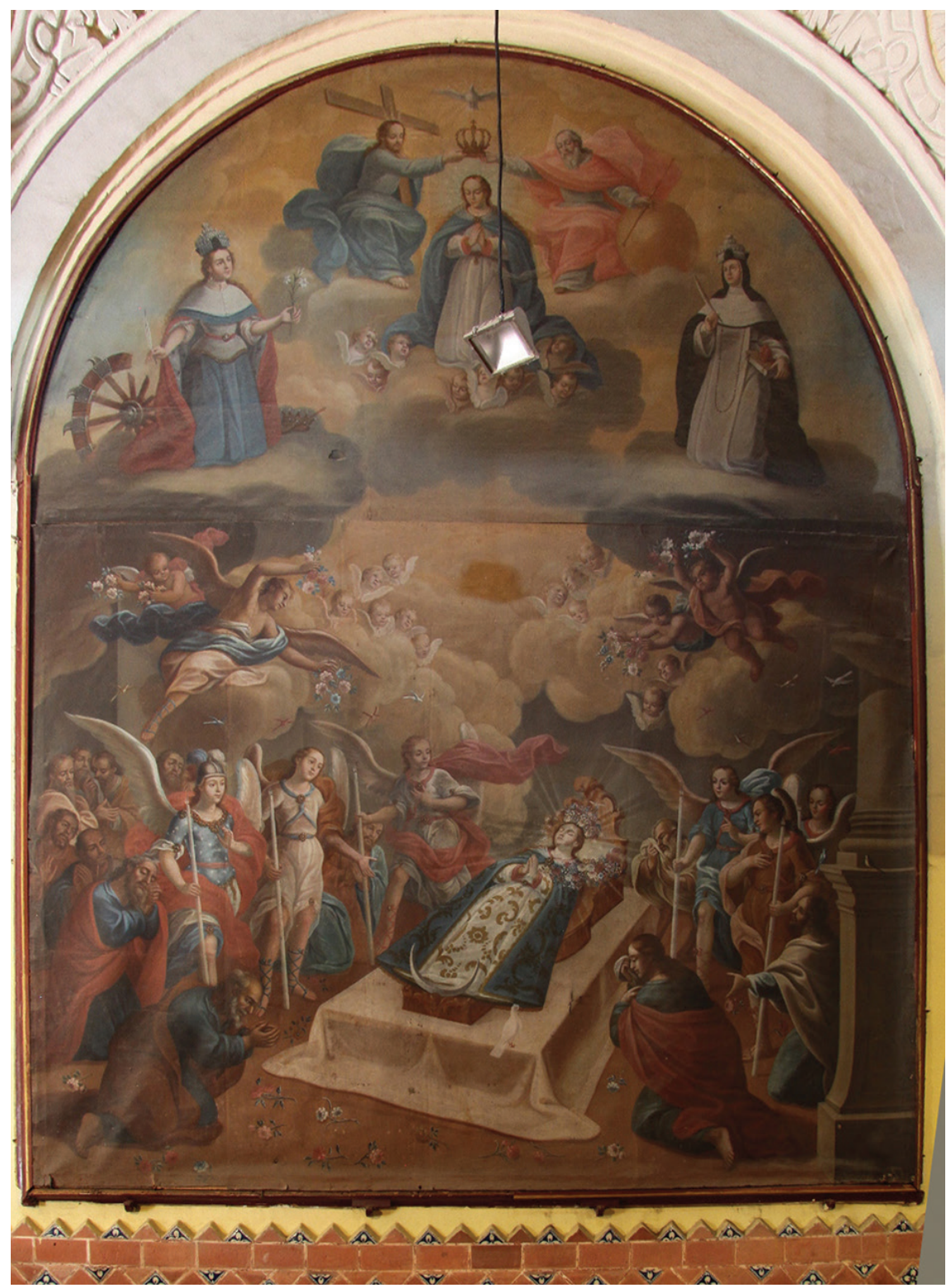

9. Anónimo, La dormición y la coronación de la Virgen con santa Catalina de Alejandría y santa Catalina de Siena, primera mitad del siglo Xviı, óleo sobre tela. Capilla de Mixtecos. Conjunto conventual de Santo Domingo, Puebla. Foto: Montserrat Andrea Báez Hernández. 
siglo XVIII, los dominicos llamaban a su santa escritora "seráfica doctora", y así aparece mencionada en una novena dedicada a ella, impresa en Guatemala en 1766 y escrita por fray Nicolás Rizo. ${ }^{36}$

Una última santa escritora promovida por el clero secular y por los jesuitas, cuya iconografía se vio influida por la imaginería teresiana, fue santa Gertrudis, monja escritora y mística alemana que vivió en el siglo XIII. En Yauhquemecan, como vimos, aparece representada frente a santa Teresa en su forma más tradicional: vestida de negro, con un báculo abacial en una de sus manos, y muestra en su pecho un corazón en cuyo interior se encuentra resguardado un niño Jesús. Su culto llegó a España desde el siglo xvi (la misma Teresa leyó su obra) y el biógrafo de la monja de Ávila, fray Diego de Yepes, fue también uno de sus grandes promotores a principios del siglo XVII; ${ }^{37}$ sin embargo, después de la canonización de santa Teresa en 1622 la asociación entre ambas santas decayó, creció la fama de la española y ensombreció la de la alemana. No fue sino hasta el siglo xviII que las imágenes de santa Gertrudis se multiplicaron y difundieron en todo el imperio español, tanto en Castilla, Aragón y Portugal como en Bolivia, Perú, Nueva Granada y Nueva España. La imagen se presentó en grabados, lienzos y esculturas, se colocó en retablos y se incluyó entre los santos más destacados en pinturas que mostraban la corte celestial, sobre todo asociada con el rescate de las almas del purgatorio. Además, quedaron de ella una gran cantidad de menciones en sermones, novenas, oraciones, misas y hagiografías en los cuales se enfatizaba a menudo su carácter, como alemana, de antídoto contra la herejía luterana. ${ }^{38}$

Junto con su iconografía tradicional que la mostraba con un corazón y el niño Jesús, en algunas de las representaciones novohispanas comenzó a mostrarse a la monja como escritora, frente a un bufete, un libro abierto y un tintero, como en el lienzo de Juan Tinoco o en otro que se encuentra en el Museo

36. Nicolás Rizo, Novena a mayor honra, veneración y culto de la Esclarecida Virgen y Seraphica Doctora Santa Catharina de Sena. Lustre y honra de la Sagrada Religión de Predicadores (Guatemala: imprenta de Sebastián de Arébalo, I766); José Toribio Medina, La imprenta en Guatemala (I660I82I) (Santiago de Chile: imprenta del autor, I910), I5I, entrada 316.

37. Carta de Diego de Yepes a Leandro de Granada fechada en I5 de noviembre de I603, véase Gertrudis la Magna, Segunda y última parte de las admirables y regaladas revelaciones de la gloriosa Santa Gertrudis (Valladolid: Juan de Bostillo, I607), s. p.

38. Antonio Rubial y Doris Bieńko, "La más amada de Cristo. Iconografía y culto de santa Gertrudis la Magna en la Nueva España”, Anales del Instituto de Investigaciones Estéticas XXV, núm. 83 (2003): 5-54. 
Io. Pascual Pérez Salazar, Santa Catalina de

Siena con birrete, primera mitad del siglo xviII, óleo sobre tela. Museo de Arte Religioso de Santa Mónica de Puebla. Secretaría de Cultura-INAH-Méx. "Reproducción autorizada por el Instituto Nacional de Antropología e Historia”.



Universitario de Puebla. Este tipo de representación fue más común en Perú y en ella se ve clara la huella de la iconografía teresiana. A esa misma influencia se debe un grabado de José de Nava de finales del siglo XviII, muy difundido en Puebla, en el cual santa Gertrudis aparece con el niño Jesús en los brazos, sin el libro, pero ya coronada con el birrete doctoral (fig. II).

\section{Las representaciones de escritoras contemporáneas}

El modelo de las mujeres escritoras antiguas (las dos Catalinas y Gertrudis), consagrado con la imagen de santa Teresa e implantado a partir de la propaganda teresiana, muy pronto fue copiado por las otras órdenes religiosas y abrió las pautas para que aparecieran nuevas representaciones de mujeres sabias "contemporáneas".

Los primeros que iniciaron este "descubrimiento" fueron los franciscanos, quienes encontraron en la visionaria María de Jesús de Ágreda (I602-I665) 
su mejor ejemplo. Esta monja, autora de un popular libro, Mistica ciudad de Dios, puso el tema de la ciencia infusa en el centro de su discurso, lo cual abrió múltiples discusiones alrededor de su inspiración, tanto a favor como en contra. El libro pretendía ser una biografía de la Virgen dictada por ella misma e inmersa en una perspectiva apocalíptica centrada en la imagen de la Inmaculada Concepción: Jerusalén, al igual que María, era centro y escenario de las maravillas del Altísimo; ambas se asociaban también con el arca de la alianza y en ellas estaban "cifradas todas las gracias y excelencias de la Iglesia triunfante y militante". ${ }^{39}$ La ciudad celeste, lo mismo que María lo hiciera con el templo de Diana en Éfeso, había vencido también al demonio y extirpado la idolatría. A partir de la obra de la madre Ágreda, la imagen de la Inmaculada, mujer vestida de sol del Apocalipsis, quedó indeleblemente unida a la de la Jerusalén celeste. $4^{4}$

La causa de la beatificación de la monja se inició tres años después de su muerte en I668, y su obra más polémica se publicó en I670. Sin embargo, la curia romana condenó la Mistica ciudad de Dios en i68I y la incluyó en el índice, siendo una de las principales acusaciones contra ella que la autora mantenía las doctrinas de Duns Scoto como divinamente reveladas. Con todo, al poco tiempo, el papa ordenó la supresión del decreto para España y Portugal y en I686 la Inquisición española, que también había puesto reparos a la obra desde su aparición junto con 16 universidades, daba un fallo favorable a su difusión. ${ }^{41}$ No obstante, todavía en I69o llegaban a la Nueva España "tres edictos de la Inquisición prohibiendo los escapularios, oratorios, libros de la monja Ágreda y cruces" ${ }^{42}$ Como se puede observar, se había desarrollado toda una parafernalia devocional alrededor de la monja concepcionista a pesar de los pruritos $\mathrm{y}$ de las prohibiciones inquisitoriales.

Esa "desobediencia" fue especialmente notoria en los territorios de la América septentrional, donde las imágenes de la madre Ágreda recibieron una gran difusión, no sólo porque la Mistica ciudad de Dios se volvió un pilar funda-

39. María de Jesús de Ágreda, Mistica ciudad de Dios, ed. Celestino Solaguren (Madrid: Fareso, 1992), lib. I, cap. I7, parr. 250.

40. Antonio Rubial, "Civitas Dei in Novus Orbis, La Jerusalén celeste en la pintura novohispana", Anales del Instituto de Investigaciones Estéticas XX, núm. 72 (primavera 1998): 5-35.

4I. Un problema similar se dio en Francia a raíz de la edición de la Mistica ciudad de Dios en francés en 1695 , lo cual desató una pugna entre marianos y antimarianos, estos últimos apoyados por los jansenistas. Celestino Solaguren, introducción a la Mistica ciudad de Dios, XXXVII y ss.

42. Antonio de Robles, Diario de sucesos notables, 3 vols. (Ciudad de México: Porrúa, 1972), II, 2II. "Domingo 24 [septiembre de I690]. 
II. José de Nava, Santa Gertrudis, I793, grabado, tomado de Francisco Pérez Salazar, El grabado en la ciudad de Puebla de los Ángeles

(Puebla: Gobierno del Estado de Puebla, Secretaría de Cultura, 1990), 53.



mental del inmaculismo novohispano, sino también por su asociación con las misiones franciscanas en el norte del territorio. De hecho, desde las últimas tres décadas del siglo XviI esta orden fue tejiendo poco a poco una leyenda apoyada por supuestos testimonios indígenas que hacían aparecer a sor María como una señora de azul que había anunciado a los indios la llegada de los franciscanos. Los misioneros en Nuevo México y Texas aseguraban que estas tradiciones indígenas tenían una enorme difusión en el norte, desde la región de los ocoroni y el Nuevo México hasta Canadá. ${ }^{43}$ La leyenda se vio reforzada, además, por la rebelión indígena que durante I2 años (I680-I692) arrebató Nuevo México del dominio español y produjo la muerte de $2 \mathrm{I}$ franciscanos. ${ }^{44} \mathrm{El}$ cronista de la orden, fray Agustín de Vetancurt, en su Teatro mexicano (impreso en I698), daba una extensa noticia respecto a la intervención de la madre

43. Existen muchos estudios sobre la relación de esta monja (conocida por los indios como "la mujer de azul") con las misiones norteńas, sobre todo en los Estados Unidos. Véase William H. Donahue, "Mary of Ágreda and the Southwest United States", The Americas, núm. 9 (1953): 29I-3I4, también, Rubial "Dos santos sin aureola", 570 y ss.

44. Isidro Sariñana, Oración fúnebre... en las exequias de 2 I religiosos... de san Francisco que murieron a manos de los indios apóstatas de la Nueva México (Ciudad de México: 168I). 
Ágreda en la conversión de los xumanas y con ello aumentaba su fama y la de los frailes. ${ }^{45}$ Pero fueron sobre todo los colegios de Propaganda Fide los que difundieron con mayor entusiasmo estas leyendas, convirtiéndolas en uno de los principales instrumentos de difusión de sus logros misioneros.

En este ámbito apareció una de las primeras representaciones de la madre Ágreda en la Nueva España, la realizada por el pintor criollo Cristóbal de Villalpando en 1706 para el convento-colegio de Propaganda Fide de Guadalupe en Zacatecas (lugar donde hoy se conserva). El cuadro, titulado La mística ciudad de Dios inscrito bajo los muros de una luminosa Jerusalén celeste, muestra a la monja Ágreda y a un san Juan Evangelista nimbado plasmando con sus plumas, en sendos libros, la visión apocalíptica de una Inmaculada que sobrevuela la ciudad de las I2 puertas. Clara Bargellini ha señalado atinadamente la vinculación de este cuadro con el grabado del frontispicio de la primera edición de la obra de sor María impresa en Madrid en 1670, aunque con una diferencia pues en el grabado, además de san Juan, aparece Duns Scoto como acompańante de la monja. ${ }^{46}$ Este grabado debió tener gran difusión pues se encuentra representado con mayor fidelidad que en la obra de Villalpando en un lienzo anónimo del Museo de Arte Religioso de Santa Mónica de Puebla en el que san Juan y la madre Ágreda (quien recibe la inspiración directa del Espíritu Santo) comparten el espacio iconográfico con Scoto, el doctor sutil. También en este cuadro se ha conservado la distinción que hacía el grabado entre las figuras canonizadas (san Juan y la Virgen) representadas con aureola, de aquellas que sólo eran consideradas venerables. Sobre todo los colegios de Propaganda Fide fueron grandes promotores de esa iconografía, pero a diferencia de santa Teresa, el birrete debía ir acompañado por la santidad, por eso sor María de Ágreda no lo llevaba.

Un caso excepcional en este sentido es el gran lienzo que representa el árbol de la familia franciscana que estaba en su templo en Toluca y que es en la actualidad el sagrario de la catedral de esa ciudad. En él, tres monjas con el hábito de las concepcionistas portan en sus cabezas birretes doctorales, una de ellas es sin duda la madre Ágreda y otra Beatriz de Silva, la fundadora de la orden. Una cuarta religiosa con hábito pardo (quizás una terciaria) trae el bonete en

45. Agustín de Vetancurt, Teatro mexicano (Ciudad de México: Porrúa, 1982), parte IV, 96.

46. Clara Bargellini describe este grabado y hace un estudio del cuadro en el libro que coordinaron Juana Gutiérrez Haces, Pedro Ángeles, Clara Bargellini y Rogelio Ruiz Gomar, Cristóbal de Villalpando, 317 y ss. 




I2. Anónimo, Árbol genealógico de la familia franciscana, detalle, mediados del siglo xviII, óleo sobre tela. Sagrario de la catedral de Toluca. Foto: Pedro López Agustín.

la mano mientras mira hacia la rama superior del árbol donde están representados los varones, varios de ellos también con el birrete doctoral (fig. I2). ${ }^{47}$

El modelo de la mujer escritora también tuvo su continuidad en dos religiosas novohispanas del siglo XVIII cuyas obras estuvieron fuertemente influidas por la gran difusión que tuvo en América la obra mística de santa Teresa de Ávila. Fue también por eso que ambas recibieron la publicidad suficiente como para que sus libros se imprimieran e igualmente que a las dos se les hicieran retratos en los cuales el modelo teresiano estaba presente. Hace casi 20 años Kathleen Myers y Amanda Powell dieron a conocer los escritos de María de San Joseph (I656-I719), una monja agustina recoleta poblana, dirigida del obispo Manuel Fernández de Santa Cruz, connotada escritora mística y visionaria y una de las fundadoras del monasterio de Nuestra Señora de la Soledad en Oaxaca en 1697. A lo largo de las 2000 páginas que abarcaban sus diarios, la religiosa describía sus visiones, profecías, enfermedades y dificultades interiores, acompañadas de noticias de la vida cotidiana y de su acti-

47. Agradezco a Mario Sarmiento la referencia a este excepcional lienzo. 
vidad como priora y fundadora..$^{8} \mathrm{~A}$ su muerte, en I7I9, el obispo de Oaxaca, Ángel Maldonado, encargó al dominico criollo Sebastián Santander y Torres, quien predicó su sermón fúnebre, la elaboración de una Vida de la monja (que incluyó abundantes párrafos de su autobiografía espiritual) y la edición de unas Estaciones devocionales a la Virgen escritas por ella. El Sermón se imprimió en Puebla, la Vida recibió dos ediciones, una en México y otra en Sevilla, mientras que las Estaciones se publicaron en numerosas ocasiones en esos tres lugares.

La publicación de una obra mística escrita por una mujer no era algo común, pero en la Nueva España se dio un segundo caso de este tipo, el de la religiosa poblana sor María Anna Águeda de San Ignacio (I695-1756), primera priora y fundadora del convento de religiosas dominicas de Santa Rosa, quien además de llevar una vida de santidad escribió varias obras místicas. El obispo de Puebla, Pantaleón Álvarez Abreu, promovió en 1758 la edición de sus trabajos Mar de gracias que comunicó al altísimo a María Santísima y Misterios del Santísimo Rosario, con una introducción biográfica del jesuita veracruzano Joseph de Bellido y el sermón fúnebre que predicó el dominico poblano Juan de Villa Sánchez. A partir de una exposición sistemática de las virtudes tomada de la obra de santo Tomás de Aquino y basada en las metáforas que utilizara san Juan de la Cruz para describir el viaje del alma, sor María ofrecía una visión original en la cual el tema de la leche de la Virgen ocupaba un papel central, por ser la fuente de donde brotó la sangre redentora de Cristo (fig. I3).

Unos años antes de que se publicara la obra de sor María Anna, el pintor Miguel Cabrera pintaba el cuadro emblemático de la "décima musa", sor Juana Inés de la Cruz, que custodia el Museo Nacional de Historia del Castillo de Chapultepec. La afamada religiosa jerónima, convertida desde el siglo anterior en una de nuestras glorias patrias, aparece representada frente a su escritorio, con un tintero lleno de plumas, con la mano sobre un libro abierto y con una biblioteca impresionante a sus espaldas. ¿Quién puede dudar que al realizarlo, el pintor oaxaqueńo tuviera en mente la muy difundida iconografía teresiana?

Sor Juana, al igual que Teresa de Ávila, María de Jesús de Ágreda, María de San José o María Anna de San Ignacio encontraron en el convento el único 
13. José Benito Ortuño, Sor María Anna Águeda de San Ignacio, 1758 , grabado, tomado de Imprentas, ediciones y grabados de México Barroco (México: Pinacoteca Virreinal, 1995),

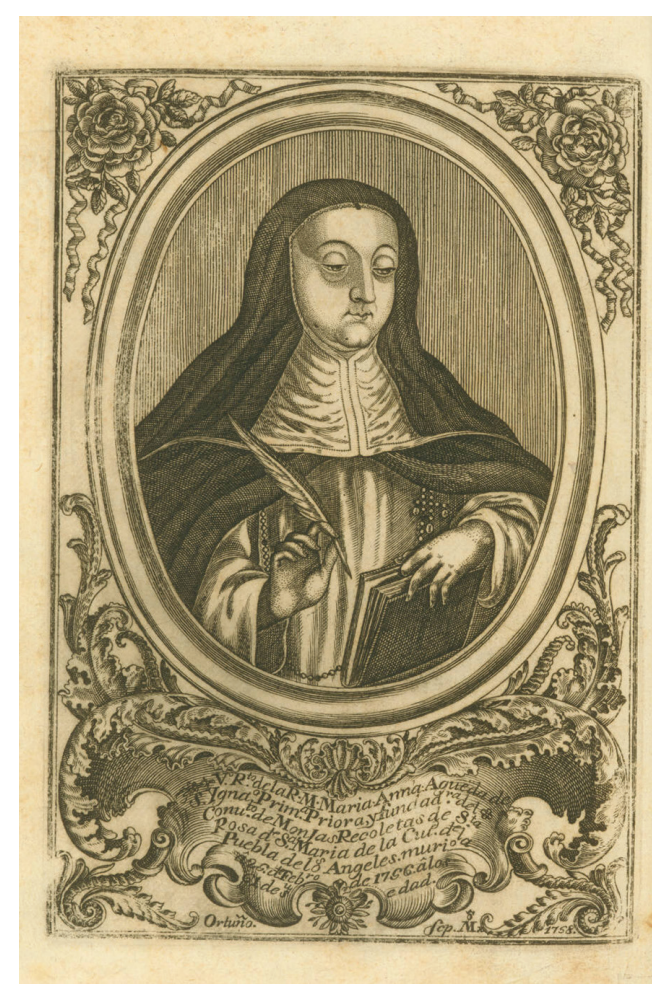

espacio de autonomía y conocimiento que la sociedad de su tiempo permitía a las mujeres. En él, el aprendizaje de la retórica, por medio de los sermones y la literatura hagiográfica, les daba las herramientas conceptuales para escribir, podían disfrutar del tiempo y del prestigio que les permitía crear, libres de maridos opresores y demandantes y sólo sujetas a unos confesores bastante tolerantes y a unos obispos respetuosos, en general, de sus mecanismos de autogestión. No existía en el ámbito protestante una situación semejante.

\section{Epilogo}

La representación iconográfica que mostraba a mujeres en el acto de escribir era un reflejo de los profundos cambios que estaba viviendo la cultura occidental 
entre el barroco y la Ilustración. La ruptura de las estructuras estamentales del Antiguo Régimen estaba propiciando el ascenso de nuevos sectores sociales, como los mercaderes y los funcionarios quienes, al igual que sus mujeres, comenzaron a tener acceso a la educación y generaron nuevos valores seculares. Un aspecto fundamental de esa laicización fue, sin duda, la mayor injerencia de las mujeres seglares en la religión. Además del notable fortalecimiento de la presencia femenina en cofradías y hermandades en este periodo, es significativa la mayor atención que mostraron predicadores y directores de conciencia hacia ellas y el incremento considerable de instituciones de religiosas de vida activa dedicadas al cuidado y la educación de las mujeres, como la Compañía de María, las ursulinas o las hermanas de la caridad. ${ }^{49}$ En ese contexto debemos entender la difusión, desde el siglo XVII, de escenas en las que santa Ana enseña a leer y escribir a la Virgen niña en un cómodo y acogedor ambiente doméstico lleno de cojines y rico mobiliario. A pesar de que el tratadista español Francisco Pacheco condenó esa representación en su Arte de la pintura por parecerle absurda (pues María había nacido con la ciencia infusa y con una sabiduría ingénita), ${ }^{50}$ el tema tuvo cierta difusión en España y América como un reflejo de la nueva actitud hacia la educación femenina, aunque dicha actitud considerara a la mujer como un mero instrumento de expansión de la enseñanza religiosa en el mundo doméstico. Para entonces varias mujeres, especialmente en el ámbito conventual, estaban utilizando este instrumento y sus obras se publicitaban gracias a la imprenta. Se podría decir que se habían masculinizado al practicar una actividad que hasta tiempos recientes estaba prácticamente monopolizada por los hombres. No obstante esto, en muchos cuadros, escritos y sermones se seguía considerando que la cualidad propia de las mujeres era la emotividad y que la racionalidad era un atributo más bien masculino.

A pesar de que la mayor parte de las obras pictóricas aquí estudiadas fueron promovidas por agentes varones con la finalidad de promocionar a sus corporaciones e institutos, en muchos casos dichas pinturas se encontraban en espacios de acceso público y, por tanto, tuvieron una cierta influencia en la conformación de una conciencia colectiva. Se puede decir que el birrete de santa Teresa (como fenómeno mediático) y la teoría de la ciencia infusa (como

49. Ronnie Po-Chia Hsia, El mundo de la renovación católica, I540-I770, trad. Sandra Chaparro Martínez (Madrid: Akal Editores, 20I0), I75 y ss. Véase también Angélica Velázquez Guadarrama, "De la caridad religiosa a la beneficencia burguesa: la dádiva social y sus imágenes", Anales del Instituto de Investigaciones Estéticas XXXVIII, núm. Io9 (otoño 2016): 45-95.

50. Francisco Pacheco, Arte de la pintura (Madrid: Cátedra, 1990), 582 y ss. 
paradigma teológico) fueron factores que incidieron en el reconocimiento de la capacidad intelectual de las mujeres en el siglo xviII. A pesar de su exclusión de la universidad y la educación formal superior, esos espacios donde se consideraron como transmisoras de la sabiduría divina se convirtieron en los primeros síntomas de un largo proceso que aún no concluye. Hasta el siglo xx, por ejemplo, la Iglesia católica reconoció la capacidad intelectual de algunas santas otorgándoles oficialmente el título de doctoras: Paulo VI nombró con esa dignidad a santa Teresa de Ávila y a santa Catalina de Siena en 1970. En 1997, Juan Pablo II se lo otorgó a santa Teresita del Niño Jesús. Y hasta 2012 Hildegarda de Bingen fue canonizada y declarada doctora por Benedicto XVI. Tales actos, consecuencia de la presión ejercida por los movimientos feministas actuales, es apenas una expresión de lo rezagada que está la Iglesia católica respecto a los acelerados cambios del mundo moderno. ${ }^{5 \mathrm{I}} \mathrm{s}$

5I. Esta investigación no hubiera sido posible sin el apoyo de quienes me ayudaron en la recolección de materiales documentales e imágenes: Mario Sarmiento, Doris Bieñko, María Fernanda Malpica, Montserrat Báez Hernández, Alejandro Andrade y Víctor Cruz Lazcano.

N.B. El presente artículo es una versión extensa de una ponencia presentada en el congreso Saberes y Enseñanzas en la América Colonial, siglos XVI-XviI, llevada a cabo en el Centro de Estudios de América Colonial en la Universidad de Barcelona, España, entre el 20 y el 22 de octubre de 2016. 